Békés Megyei Központi Kórház, Pándy Kálmán Tagkórház, Gyermekosztály, Gyula, ${ }^{1}$ Pécsi Tudományegyetem, Gyermekklinika² $^{2}$

\title{
Hogyan befolyásolja a táplálék zsír- és/vagy fehérjetartalma a postprandialis hyperglykaemiát? Prandialis inzulinbólus algoritmusok pumpakezelésben részesülö 1-es típusú diabeteses gyermekekben
}

\author{
H. Nagy Katalin dr., ${ }^{(1)}$ Soltész Gyula dr. ${ }^{(2)}$
}

\begin{abstract}
Osszefoglalás
A zsir- és/vagy fehérjedús étkezés hatását, valamint az ezzel kapcsolatosan kidolgozott inzulinbólus-stratégiákat elemeztük pumpakezelt diabeteses gyermekekben az irodalmi adatok tükrében és elsö tapasztalataink alapján. A postprandialis vércukorszint jelentös meghatározója a glikált hemoglobin értékének. A postprandialis hyperglykaemia fontos, független rizikótényezö a késöi szövődmények kialakulása szempontjából, és ma is a vércukorszint optimalizálásának egyik fö problémája 1-es típusú diabeteses betegekben. A prandialis inzulinszükséglet meghatározásának hagyományos módja a szénhidrátszámolás. Egyre több bizonyiték szól azonban amellett, hogy a többi makronutrienst is figyelembe kell venni a prandialis inzulinszükséglet kiszámitásához. Különösen a zsirban és fehérjében gazdag ételek elfogyasztását követöen mutatták ki, hogy legalább 5 órán keresztül megnövelik a postprandialis glykaemiát, ami arra utal, hogy ilyen ételek fogyasztása elött pluszinzulin beadására van szükség. Ezért az ételek zsir-és fehérjetartalmát is számba vevö prandialis inzulin algoritmusokat fejlesztettek ki. llyen a Pankowska-módszer, a táplálék-inzulin index és legújabban egy olyan szoftver, amely (beszédfelismeröt és táplálék-adatbázist is felhasználva) az ételek teljes kalóriatartalmát figyelembe veszi. Kétségtelen, hogy a zsir- és fehérjedús ételek fogyasztása elött addicionális inzulin beadására van szükség, de az optimális algoritmus kidolgozása még nem történt meg. Jelenleg a prandialis dózis individuális meghatározása a követendö gyakorlat. Az ISPAD kezelési irányelve egy kezdö 15-20\%-os inzulinadag-emelést javasol zsir- és fehérjedús ételek elfogyasztás elött. Ennek hatásosságát folyamatos szöveti glukóz vagy strukturált vércukorméréssel szükséges megerösiteni.
\end{abstract}

Kulcsszavak: postprandialis vércukor, inzulinbólus-algoritmus, szénhidrátszámolás, zsir, fehérje

\section{How postprandial hyperglycaemia is modified by high fat and/or high protein meals? Prandial insulin-dosing algorithms in insulin pump-treated children with Type 1 diabetes}

Summary: This overview summarizes the recent data on the glycaemic effects of high fat and/or high protein meals in healthy and diabetic individuals, as well as on the prandial bolus strategies in insulin pump treated diabetic children. Postprandial blood glucose is an important determinant of glycated hemoglobin, postprandial hyperglycemia is an independent risk factor for the development of microvascular complications, and remains a clinical challenge in optimizing glucose control in Type 1 diabetes. Carbohydrate counting or quantification is traditionally recommended for prandial insulin dose estimation. However, there is growing evidence that other macronutrients should also be taken into account when determining the prandial insulin dose. In particular, high fat and high protein meals have been shown to increase postprandial glycaemia for at least 5 hours, suggesting that additional insulin may be required for meals with high fat or protein content. Algorithms have been proposed which take into account the glycaemic impact of fat and protein. These include the 
Pankowska equation and the food insulin index, and recently a novel algorithm (using a speech recognition software and a food database), where the insulin dosage is based on the total calorie value of a meal. While additional insulin may be required for high fat and protein meals, the ideal meal bolus algorithm has yet to be determined. Currently, an individualized approach to insulin dosing is best practice for people with Type 1 diabetes. The ISPAD guideline suggests a starting level of 15-20\% additional insulin for high fat and protein. The effectiveness of the insulin-dosing approach for the individual should be confirmed with CGM or structured postprandial glucose testing.

Key words: postprandial blood glucose, insulin bolus algorithm, carbohydrate counting or carbohydrate quantification, fat, protein

DIABETOLOGIA HUNGARICA 27 (№3) 147-154. 2019. szeptember DOI: $10.24121 / \mathrm{dh} .2019 .10$

Rövidítések

GIP: enterohormon (gastric inhibitory polypeptide); ISPAD: International Society for Pediatric and Adolescent Diabetes

A postprandialis vércukorszint jelentős meghatározója a glikált hemoglobin értékének, és a pp. hyperglykaemia fontos, független rizikótényező a késői szövődmények kialakulása szempontjából. Mindez új megvilágításba került annak a ténynek az ismételt előtérbe kerülésével, hogy diabetesesekben az étkezési szénhidrátok mellett az elfogyasztott zsírok és fehérjék is vércukoremelő hatással bírnak. Nem elhanyagolható mennyiségekről van szó, hiszen az ajánlások szerint a zsírok a napi kalóriabevitel mintegy 30\%át, a fehérjék pedig 15-20\%-át teszik ki.

$\mathrm{Az}$ inzulinpumpa-kezelés egyik meghatározó előnye, hogy az ételek szénhidrát-, zsír- és fehérjetartalmának ismeretében, az étkezés előtti bólusok adagjának és típusának (egyszerű vagy standard, szögletes vagy elhúzódó és kombinált, kettős hullámú) megválasztásával hatékonyabban mérsékelhető a postprandialis hyperglykaemia, mint az injekciós inzulinkezeléssel.

A zsír- és/vagy fehérjedús étkezéseket megelőző optimális inzulinbólus meghatározására az utóbbi években számos kísérlet történt, aminek már tekintélyes nemzetközi irodalma van. Tudomásunk szerint azonban mindeddig magyar nyelven sem szakmai összefoglaló vagy ajánlás, sem páciensedukációs anyag nem született e témában.

Közleményünkben összefoglaljuk az étkezési zsírok és fehérjék vércukor- és anyagcserehatásait egészségesekben és diabetesesekben, valamint áttekintést adunk a zsír- és/vagy fehérjedús étkezést követő vércukor-emelkedés mérséklésére kidolgozott „bólus-stratégiákról”.
Zsírok

A zsírokat mint makrotápanyagokat rendszerint szénhidrátokkal együtt fogyasztjuk, ritkán önmagukban. A szénhidrátokkal együtt fogyasztott zsírok mind az anyagcsere-egészségesekben, mind az 1-es típusú diabetesesekben az étkezések utáni első 3 órában mérséklik azok vércukoremelő hatását, de elhúzódó, későbbi hyperglykaemiát okoznak. ${ }^{1,2,3,4,5}$ Ez ronthatja a glykaemiás helyzetet, és mivel a magas zsírtartalmú ételek gyakran a vacsoraidőben kerülnek az asztalra, a hyperglykaemiára sokszor csak reggel derül fény. ${ }^{6}$

A zsírok vércukorszintet befolyásoló hatásának mechanizmusa összetett. ${ }^{7}$

1. Glukoneogenezis glicerolból: A lipidek mintegy $90 \%$-át trigliceridek alkotják. A tömegük 5-15\%-át kitevő glicerol egy része a glukoneogenezisben glukózzá alakul, a maradék a glukolízis útjára lép. ${ }^{8}$

2. A szabad zsírsavak direkt hatása: A keringő szabad zsírsavak a béta-sejtekben fokozzák a glukóz stimulálta inzulinszekréciót (amit egy G-proteinnel társuló receptorral történő interakciónak tulajdonítanak). ${ }^{8}$ Ugyanakkor a szabad zsírsavak PPAR- (peroxysoma-proliferátor aktiválta receptor) ligandok is. ${ }^{9}$

3. Egyéb hormonokra gyakorolt hatás: Megváltoztatják egyes vércukor-szabályozást befolyásoló hormonok (glukagon, glukagonszerü fehérje 1 [GLP-1], gastric inhibitory polypeptide [GIP], ghrelin) elválasztását. Anyagcsereegészségesekben az önmagában fogyasztott 
zsír a glukagon és a GLP-1 szintjének emelkedését okozta, de ha a zsírt szénhidráttal együtt fogyasztották, ez az emelkedés elmaradt. ${ }^{10} 1$-es típusú diabeteses serdülőkben magas zsír- és magas szénhidráttartalmú ételek fogyasztását követően a GLP-1, a GIP és a ghrelin szintje növekedett. ${ }^{11}$

4. A gyomorürülésre gyakorolt hatás: A gyomorürülés a glukózfelszívódás sebességét meghatározó egyik fontos tényező. A gyomor folyamatos $2 \mathrm{kcal} / \mathrm{min}$ energiaütemben ürül. Zsír hozzáadása az étkezéshez lassítja a szénhidrátok ürülését a gyomorból. ${ }^{5,7}$ Egészséges egyénekben zsírok hozzáadása az elfogyasztott szénhidrátokhoz csökkentette azok vércukoremelő hatását. Azt is megfigyelték, hogy a zsírsavláncok hossza és telítettsége is befolyásolja az étkezést követő glykaemiás választ. ${ }^{12}$ A zsírok még a következő étkezés után is lassíthatják a gyomorürülést. Kimutatták, hogy a reggeli étkezés zsírtartalma még az ebédet követő gyomorürülést is lassította. ${ }^{13}$

\section{Fehérjék}

A fehérjék fogyasztása anyagcsere-egészségesekben nem befolyásolja a vércukorszintet az aminosavak felvételéhez szükséges jelentős postprandialis inzulinelválasztás ellenére. ${ }^{14,15}$ Ennek oka az, hogy egyidejűleg a glukagonelválasztás is fokozódik, és ennek hatására glukóz szabadul fel a májból. Diabetesesekben azonban az étkezés fehérjetartalmának megnövelése elhúzódó hyperglykaemiához vezet, ami 2-3 óra elteltével kezdődik és 5 órán túl is tarthat. ${ }^{5,16}$ Ennek a megfigyelésnek fontos klinikai jelentősége van az étkezés előtti inzulin dózisának és beadási módjának megtervezésében.

Ami a mechanizmust illeti, több magyarázat is felmerült: ${ }^{7}$

1. Glukoneogenezis: Ha nincs elegendő inzulin, emelkedik a glukogén aminosavak felvétele a májban, fokozódik a glukoneogenezis, és emelkedik a vércukorszint.

2. Glukagon: Fehérjefogyasztást követően mind egészségesekben, mind 1-es típusú diabetesesekben a glukagonelválasztás növekedése figyelhető meg. Míg egészségesekben azonban ennek vércukoremelő hatását az egyidejüleg fokozódó inzulinelválasztás semlegesíti, addig az 1-es típusú diabetesesekben a glukagonszint emelkedése inzulin hiányában étkezés utáni hyperglykaemiához vezet ${ }^{17,18}$ (1. később!).

3. Egyéb hormonális hatások: Magas fehérjetartalmú ételek fokozzák a kortizolelválasztást (ami viszont növeli az inzulinrezisztenciát és az inzulinigényt ${ }^{19}$ ), emelik az IGF-1 szintjét, és csökkentik a ghrelinszintet. ${ }^{20}$

A magas fehérje-/alacsony szénhidráttartalom emeli a növekedési hormon szintjét, a magas fehérje-/magas szénhidráttartalom nem változtatja meg vagy csökkenti e hormon szintjét. ${ }^{21}$

\section{Zsírok és fehérjék}

Diabeteses egyénekben tehát a zsírok és a fehérjék önmagukban, egymástól függetlenül is vércukoremelő hatásúak. Mivel azonban a legtöbb elfogyasztott táplálék zsírt és fehérjét is tartalmaz, klinikai körülmények között egyidejü hatásukkal kell számolnunk. A vizsgálatok szerint ilyenkor a két táplálék vércukoremelő hatása összegződik. ${ }^{16,22}$

\section{Makronutriensek és prandialis inzulin}

A legtöbb táplálék, amit elfogyasztunk, mindhárom makronutrienst tartalmazza. Ebből következik, hogy zsír- és/vagy fehérjedús táplálék elfogyasztása előtt a prandialis inzulin bólusát úgy kell megválasztanunk, hogy az mind a korai, mind a késői hyperglykaemiát mérsékelje.

\section{Korai hyperglykaemia}

Magas szénhidráttartalmú étel elfogyasztása esetén nagyon fontos a korai vércukorkiugrás megelőzése, mert ez befolyásolhatja a teljes postprandialis időszak vércukorszintjének alakulását. Ez különösen érvényes akkor, ha az étel zsír- és fehérjetartalma is jelentős, ami tovább fokozza a késői postprandialis vércukor-emelkedést.

\section{Késői hyperglykaemia}

A sikeres prandialis inzulinkezelés további feltétele (a szénhidráttartalom mellett) az elfogyasztandó étel zsír- és fehérjetartalmához szükséges 
pluszinzulinadag helyes kiszámolása és a megfelelő bólustípus kiválasztása.

Egy szisztémás irodalmi áttekintésen alapuló összefoglaló az inzulinadag tekintélyes, mintegy 30-65\%-os megemelését és annak szögletes vagy kombinált bólus formájában történő beadását javasolta. ${ }^{23}$

Az utóbbi időben speciális algoritmusokat is kidolgoztak a zsír- és fehérjéhez „szükséges” pluszinzulinadag kiszámolásához:

\section{Pankowska-módszer: Zsirr-fehérje egység}

A gyermekdiabetológiai irodalomban legjobban elterjedt algoritmus Pankowska lengyel gyermekdiabetológus nevéhez füződik, ezért részletesebben ezt ismertetjük. ${ }^{24}$

A tapasztalati alapon kifejlesztett algoritmus két alapelven nyugszik, az úgynevezett zsír-fehérje egység definiálásán és az egy zsír-fehérje egység inzulinigényének meghatározásán.

Egy zsír-fehérje egység 100 kcal energiatartalmú zsírnak vagy fehérjének felel meg. Mivel 1 gramm fehérje energiatartalma 4 kcal, ezért 25 gramm fehérje $(25 \times 4=100)$ per definitionem 1 zsír-fehérje egység. Mivel 1 gramm zsír energiatartalma 9 kcal, 11 gramm zsír $(11 \times 9=100)$ tesz ki 1 zsír-fehérje egységet.

Egy zsír-fehérje egység elfogyasztása előtt beadandó inzulin - Pankowska tapasztalata alapján - megfelel a 10 gramm szénhidrát beviteléhez szükséges inzulinnak, azaz megegyezik a pumpakezelésben általánosan használt inzulin:szénhidrát aránnyal.

Mivel a 10 gramm szénhidráthoz szükséges inzulin egyénenként különböző (és napszakonként is változhat), ebből következően a zsír-fehérje egységre számított inzulin is eszerint módosul.
Például akinek 10 gramm szénhidráthoz 1,5 egység inzulin kell, annak - ha a 10 gramm szénhidrátot tartalmazó étele még 1 zsír-fehérje egységnyi zsírt és/vagy fehérjét is tartalmaz - további 1,5 egység inzulint, összesen tehát 3 egység bólusinzulint kell beadnia.

Pankowska - tapasztalaton alapuló - ajánlása szerint ilyenkor kombinált bólus adása javasolt. Ennek „első hulláma” az étel szénhidráttartalma alapján számolt egyszerű vagy standard bólus, második része egy szögletes bólus. Ennek időtartamát pedig az alábbi egyszerű algoritmus határozza meg:

- >1 zsír-fehérje egység: 3 óra,

- >2 zsír-fehérje egység: 4 óra,

- >3 zsír-fehérje egység: 5 óra,

- >4 zsír-fehérje egység: 8 óra.

Pankowska módszerét már számos vizsgálatban kipróbálták és használták. Alkalmazásával sikerült mérsékelni a postprandialis hyperglykaemiát, azonban számos esetben klinikailag jelentős hypoglykaemiát okozott. ${ }^{24,25,26}$

A módszerrel kapcsolatban saját tapasztalatunk egyelőre még kevés van. Illusztrációként bemutatjuk egy 9 éves gyermek pizzavacsoráját (1. táblázat), annak pontos tápanyag-összetételét és az ennek elfogyasztásához szükséges - a fenti elvek alapján számított - bólus részleteit (inzulinmennyiség és bólustípus). Vacsora alatt és azután egészen a következő nap reggeléig a gyermek folyamatos glukózérzékelőt viselt.

Az első tesztnapon (1/A. ábra) a vacsora előtt a hagyományos számítás szerint csak a vacsora szénhidráttartalmának megfelelő 3 egység inzulinbólus beadása történt. A 1/A. ábra jól érzékelteti az egész éjszaka tartó megemelkedett cukorértékeket.

Egy másik tesztnapon (1/B. ábra) ugyanazt az összetételü és mennyiségű pizzát vacsorázta, de ekkor a zsír- és fehérjetartalom alapján - Pankowska szerint kiszámolt - megemelt dózisú (a cukorszint alapján szükséges korrekciós inzulinbólust is

1. táblázat. 9 éves gyermek pizzavacsorája (1 szelet pizza: 225 g, 443 kcal/1852 kJ, összes inzulinigény: 5,4 E)

\begin{tabular}{|c|c|c|}
\hline \multirow{2}{*}{ Tápanyagösszetétel } & \multicolumn{2}{|c|}{ Inzulin } \\
\hline & Mennyiség & Bólustípus (kombinált) \\
\hline Szénhidrát & $41 \mathrm{~g}$ (inzulin/szénhidrát arány:* 0,75 E/10 g) & 3 E standard \\
\hline Zsír & $24 \mathrm{~g}=1,65$ fehérje-zsír egység & \multirow{2}{*}{ 2,4 E kiterjesztett - 4 óra } \\
\hline Fehérje & $25 \mathrm{~g}=0,75$ fehérje-zsír egység & \\
\hline
\end{tabular}

A pizza (összesen 7 szelet) nyersanyagai: $400 \mathrm{~g}$ teljes kiőrlésủ tönkölybúzaliszt, $14 \mathrm{~g}$ extra szúz olívaolaj, $14 \mathrm{~g}$ szárított élesztő, $200 \mathrm{~g}$ light ketchup, $280 \mathrm{~g}$ kukorica, $220 \mathrm{~g}$ makréla repceolajban, $250 \mathrm{~g}$ light trappista sajt.

* egyénenként változhat 


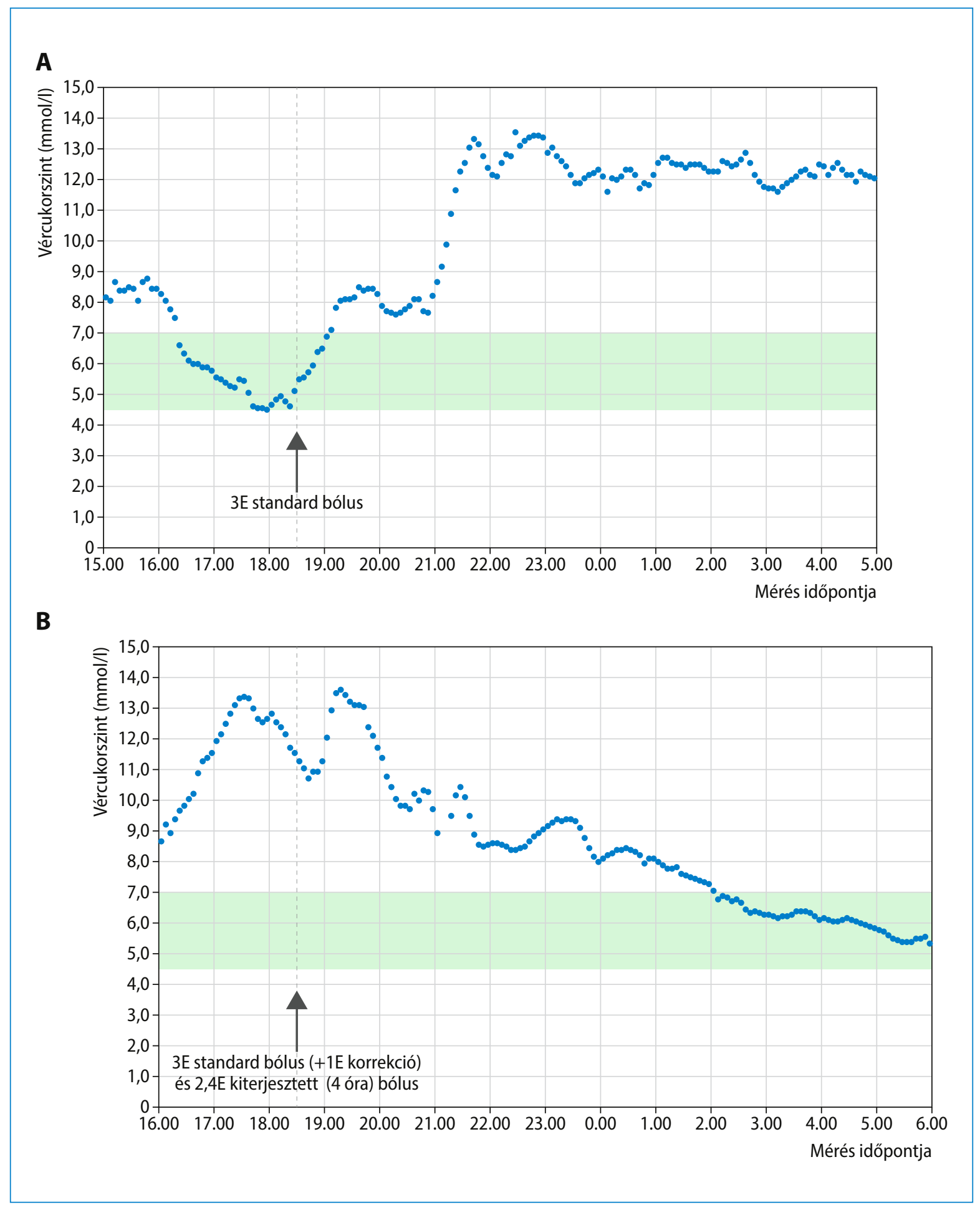

1. ábra. A vacsora szénhidráttartalmára számított standard bólus (A) és a zsír-fehérje egység inzulinigényével kiegészített kombinált bólus (B) hatása a vacsorát követő cukorértékekre 
tartalmazó) kombinált bólust kapott. Az 1/B. ábrán látható a cukorszint vacsora utáni néhány órás mérsékelt megemelkedése, amit azután az egész éjszaka során normális cukorértékek követtek. Hajnalban és a reggeli órákban megfigyelhető volt egy csökkenő tendencia, de az értékek végig a céltartományban, annak alsó részében maradtak. Az 1. ábra glukózértékeinek görbéi alapján feltételezhető, hogy a tesztételek elfogyasztását megelőzően a bázisinzulin üteme szuboptimális volt.

\section{Táplálék-inzulin index (Food Insulin Index, FII)}

A glykaemiás indexhez hasonló viszonyszám, amely a legkülönbözőbb kevert táplálékokat a szerint rangsorolja, hogy elfogyasztásukat, egészséges egyénekben, azonos energiatartalmú (izoenergetikus) referencia-étellel összehasonlítva milyen inzulinválasz követ. ${ }^{27}$

Inzulinpumpával kezelt felnőtt diabetesesekben a FII használata mérsékelte a fehérjedús étel elfogyasztását követő postprandialis hyperglykaemiát a korábban használt „egyszerü” inzulin:szénhidrát arány számolással összehasonlítva. ${ }^{28}$

Egy, a közelmúltban megjelent randomizált, keresztezett ausztrál vizsgálatban pedig mind a három prandialis inzulinbólus algoritmus (Pankowska-egyenlet, FII és inzulin:szénhidrát arány) glykaemiás hatását megvizsgálták 33 diabeteses gyermekben és kamaszban. ${ }^{29} \mathrm{~A}$ gyermekek azonos szénhidrát-tartalmú, magas fehérje- (spagetti), illetve magas zsírtartalmú (csirkefalatkák és sült krumpli) tesztételt fogyasztottak, majd folyamatos glukózérzékelővel 300 percen keresztül követték a szövetközi glukózszint alakulását. Fehérjedús étel elfogyasztása után a pp. hyperglykaemia a Pankowska-egyenlet alapján kiszámolt bólusinzulint követően volt a legkisebb fokú, de az ötödik óra végén a gyermekek egy részénél hypoglykaemia alakult ki. Zsírdús étel elfogyasztása mindhárom inzulinalgoritmus alkalmazását követően hasonló, mérsékelt pp. hyperglykaemiát eredményezett. Összességében elmondható, hogy bizonyos fokú hyperglykaemiát egyik inzulinbólus-algoritmussal sem sikerült megelőzni.

A publikált vizsgálatok összehasonlíthatóságát számos tényező nehezíti. A bólusok időtartama és formái (egyszerű, szögletes és kombinált), valamint egymáshoz viszonyított arányuk különbözött az egyes vizsgálatokban, és abban sem volt egység, hogy a bólusok beadása mennyi idővel az étkezés előtt történt. További fontos, a postprandialis vércukor alakulását befolyásoló körülmények is módosíthatták az eredményeket. Többek között például az, hogy előzőleg mennyire volt optimalizálva a bázisinzulin-infúzió üteme és a számításokhoz használt inzulin:szénhidrát arány, mennyi volt a szénhidrátok glykaemiás indexe, valamint az is, hogy milyen volt a páciens inzulinérzékenysége.

A Gyermek- és Serdülőkori Diabetes Nemzetközi Társasága (ISPAD) legújabb, 2018-ban megjelent irányelve is foglalkozik a kérdéssel, de egyelőre még nem foglalt egyértelműen állást. Ajánlása egy konzervatív megközelítés. Azt javasolja, hogy első lépésként a zsír- és/vagy fehérjedús étkezés előtt a szénhidráttartalomra számított inzulinadagot $15-20 \%$-kal emeljük meg. ${ }^{30}$ Ugyanakkor hangsúlyozza az inzulinadag individuális megválasztásának fontosságát, felhasználva a korábbi étkezéseket 6 órán keresztül követő cukormérések tapasztalatait.

Tovább finomíthatják az étkezési bólusok alkalmazását speciálisan kifejlesztett szoftverek. Ezek egyszerűbb formáival (bólus wizard vagy bóluskalkulátor) már a jelenleg forgalomban lévő pumpák (Animas, Medtronic, Roche) is rendelkeznek, de a számolásnál még kizárólag csak a páciens által megadott szénhidrát mennyiségét (glykaemiás index nélkül) veszik figyelembe.

Az újabb szoftverek már nemcsak az ételek szénhidrát-, hanem a teljes kalóriatartalmára és makronutriens-összetételére vonatkozó adatokat is felhasználva számolják ki az ajánlott prandialis inzulin dózisát. Pankowska és munkatársai egy okostelefonra feltölthető applikációt dolgoztak ki („VoiceDiab”). A szoftver automatikus beszédfelismerőt és nyelvanalizáló rendszert, egy 887-féle ételt tartalmazó táplálék-adatbázist és inzulinadagot kiszámoló („Diabetics”) algoritmust tartalmaz. A páciens bemondja a telefonba az elfogyasztandó étel részleteit, például 200 gramm marhasült, 120 gramm főtt burgonya, saláta és 100 gramm vaníliafagylalt (a cikkből vett példa). Ezt követően a képernyőn megjelenik az étel részletesen kiszámolt összetétele (szénhidrát, fehérje, zsír és öszszes kalória). Végül a páciens jóváhagyása után a képernyőn leolvasható az ajánlott inzulindózis, a bólus típusa és beadásának időtartama. Az első, 12 felnőtt diabeteses páciens bevonásával végzett, 
keresztezett, randomizált vizsgálatban a postprandialis hyperglykaemia szignifikáns mérséklődése volt megfigyelhető, a hypoglykaemiák gyakoriságának fokozódása nélkül. ${ }^{31}$ Gyermekekben, illetve serdülőkben végzett hasonló vizsgálatról nincs tudomásunk.

\section{Összefoglalás}

Elmondhatjuk, hogy a pp. hyperglykaemia megelőzésére, illetve mérséklésére kidolgozott algoritmusok és szoftverek alkalmazása - az irodalmi tapasztalatok alapján - ígéretesnek tűnik, de további kontrollált és nagyobb számú beteg bevonásával végzett, standardizált vizsgálatokra van szükség, mielőtt azok a mindennapos rutin részévé válhatnának. Egyelőre úgy tűnik, hogy az egyre javuló szoftverek alkalmazásától is csak akkor várható jó glykaemiás eredmény, ha ez társul a páciensek egyre bővülő diétás ismereteivel. Jelenleg az étkezést megelőző bólust, még az éjszakai és étkezések közötti cukorszintet automatikusan beállító, úgynevezett hibrid inzulinpumpák használata esetén is, a páciensnek kell meghatároznia.

\section{Irodalom}

1. Wolpert HA, Atakov-Castillo A, Smith SA, Steil GM: Dietary fat acutely increases glucose concentrations and insulin requirements in patients with type 1 diabetes: implications for carbohydrate-based bolus dose calculation and intensive diabetes management. Diabetes Care 2013; 36(4): 810-816. doi: $10.2337 / \mathrm{dc} 12-0092$

2. Freckmann G, Hagenlocher S, Baumstark A, Jendrike N, Gillen RC, Rössen $K$, et al.: Continuous glucose profiles in healthy subjects under everyday life conditions and after different meals. J Diabetes Sci Technol 2007; 1(5): 695-703. doi:10.1177/193229680700100513

3. Lodefalk M, Aman J, Bang P: Effects of fat supplementation on glycaemic response and gastric emptying in adolescents with type 1 diabetes. Diabet Med 2008; 25: 1030-1035. doi:10.1111/j.1464-5491.2008.02530.x

4. MacDonald K, Lowe JM, Barker D, MenschM, Attia J: Effect of popular takeaway foods on blood glucose levels in type 1 diabetes mellitus patients on intensive insulin therapy. Int I Clin Pract 2009; 63: 189-194. doi:10.1111/j.1742-1241.2008.01970.x

5. Garcia-Lopez JM, Gonzalez-Rodriguez M, Pazos-Couselo M, Gude F, PrietoTenreiro A, Casanueva F: Should the amounts of fat and protein be taken into consideration to calculate the lunch prandial insulin bolus? Results from a randomized crossover trial. Diabetes Technol Ther 2013; 15(2): 166-171. doi:10.1089/dia.2012.0149

6. Desjardins K, Brazeau AS, Strychar I, Leroux C, Gingras V, Rabasa-Lhoret R: Association between post-dinner dietary intakes and nocturnal hypoglycemic risk in adult patients with type 1 diabetes. Diabetes Res Clin Pract 2014; 106(3): 420-427. doi:10.1016/j.diabres.2014.09.015

7. Paterson M, Bell KJ, O'Connell SM, Smart CE, Shafat A, King B: The Role of dietary protein and fat in glycaemic control in type 1 diabetes: implications for intensive diabetes management. Curr Diab Rep 2015; 15(9): 61 . doi:10.1007/s11892-015-0630-5

8. Turner N, Cooney GJ, Kraegen EW, Bruce CR: Fatty acid metabolism, energy expenditure and insulin resistance in muscle. J Endocrinol 2014; 220(2): 61-79. doi:10.1530/J0E-13-0397

9. Grygiel-Gorniak B: Peroxisome proliferator-activated receptors and their ligands: nutritional and clinical implications - a review. Nutr J 2014; 13(1): 17. doi:10.1186/1475-2891-13-17

10. Radulescu A, Gannon MC, Nuttall FQ: The effect on glucagon, glucagonlike peptide-1, total and acyl-ghrelin of dietary fats ingested with and without potato. I Clin Endocrinol Metab 2010; 95(7): 3385-3391. doi:10.1210/jc.2009-2559

11. Lodefalk M, Carlsson-Skwirut C, Holst JJ, Aman J, Bang P: Effects of fat supplementation on postprandial GIP, GLP-1, ghrelin and IGFBP-1 levels: a pilot study on adolescents with type 1 diabetes. Horm Res Paediatr 2010; 73(5): 355-362. doi:10.1159/000308168

12. Clegg M, Pratt M, Markey 0, Shafat A, Henry CJK: Addition of different fats to a carbohydrate food: Impact on gastric emptying, glycaemic and satiety responses and comparison with in vitro digestion. Food Res Int 2012; 48(1): 91-97. doi:10.1016/j.foodres.2012.02.019

13. Clegg M, Shafat A: Energy and macronutrient composition of breakfast affect gastric emptying of lunch and subsequent food intake, satiety and satiation. Appetite 2010; 54(3): 517-523. doi:10.1016/j.appet.2010.02.005

14. Khan MA, Gannon MC, Nuttall FQ: Glucose appearance rate following protein ingestion in normal subjects. J Am Coll Nutr 1992; 11(6): 701-706. doi:10.1080/07315724.1992.10718270

15. van Loon $\mathrm{L}$, Saris WH, Verhagen $H$, Wagenmakers AJ: Plasma insulin responses after ingestion of different amino acid or protein mixtures with carbohydrate. Am I Clin Nutr 2000; 72(1): 96-105. doi:10.1093/ajcn/72.1.96 
16. Smart CE, Evans M, O'Connell SM, McElduff P, Lopez PE, Jones TW, et al.: Both dietary protein and fat increase postprandial glucose excursions in children with type 1 diabetes, and the effect is additive. Diabetes (are 2013; 36(12): 3897-3902. doi:10.2337/dc13-1195

17. Winiger G, Keller U, Laager R, Girard J, Berger W: Protein content of the evening meal and nocturnal plasma glucose regulation in type-I diabetic subjects. Horm Res 1995; 44(3): 101-104. doi:10.1159/000184604

18. Brown RJ, Sinaii N, Rother Kl: Too much glucagon, too little insulin: time course of pancreatic islet dysfunction in new-onset type 1 diabetes. Diabetes Care 2008; 31(7): 1403-1404. doi:10.2337/dc08-0575

19. Slag MF, Ahmad M, Gannon MC, Nuttall FQ: Meal stimulation of cortisol secretion: a protein induced effect. Metabolism 1981; 30(11): 1104-1108.

20. Blom WA, Lluch A, Stafleu A, Vinoy S, Holst JJ Schaafsma G, et al.: Effect of a high-protein breakfast on the postprandial ghrelin response. Am J Clin Nutr 2006; 83(2): 211-220. doi:10.1093/ajen/83.2.211

21. van Vught AJ, Nieuwenhuizen AG, Brummer RJ, Westerterp-Plantenga MS: Effects of oral ingestion of amino acids and proteins on the somatotropic axis. J Clin Endocrinol Metab 2008; 93: 584-590. doi:10.1210/jc.2007-1784

22. Peters AL, Davidson MB: Protein and fat effects on glucose responses and insulin requirements in subjects with insulindependent diabetes mellitus. Am J Clin Nutr 1993; 58(4): 555-560. doi:10.1093/ajcn/58.4.555

23. Bell KJ, Smart CE, Steil GM, Brand-Miller JC, King B, Wolpert HA: Impact of fat, protein, and glycemic index on postprandial glucose control in type 1 diabetes: implications for intensive diabetes management in the continuous glucose monitoring era. Diabetes Care 2015; 38(6): 1008-1015. doi: $10.2337 / \mathrm{dc} 15-0100$

24. Pankowska E, Szypowska A, Lipka M, Szpotaska M, Bazik M, Groele L: Application of novel dual wave meal bolus and its impact on glycated hemoglobin A1c level in children with type 1 diabetes. Pediatr Diabetes 2009; 10: 298-303. doi:10.1111/j.1399-5448.2008.00471.x

25. Kordonouri 0, Hartmann R, Remus K, Blasig S, Sadeghian E, Danne $\mathrm{T}$ : Benefit of supplementary fat plus protein counting as compared with conventional carbohydrate counting for insulin bolus calculation in children with pump therapy. Pediatr Diabetes 2012; 13: 540-544. doi:10.1111/j.1399-5448.2012.00880.x
26. Piechowiak K, Dżygało K, Szypowska A: The additional dose of insulin for high-protein mixed meal provides better glycemic control in children with type 1 diabetes on insulin pumps: randomized cross-over study. Pediatr Diabetes 2017; 18(8): 861-868. doi:10.1111/pedi.12500

27. Bao J, Gilbertson HR, Gray R, Munns D, Howard G, Petocz P, et al.: Improving the estimation of mealtime insulin dose in adults with type 1 diabetes: the normal Insulin Demand for Dose Adjustment (NIDDA) study. Diabetes Care 2011; 34(10): 2146-2151. doi:10.2337/dc11-0567

28. Bell KJ, Gray R, Munns D, Petocz P, Howard G, Colagiuri S, et al:: Estimating insulin demand for protein-containing foods using the food insulin index. Eur J Clin Nutr 2014; 68(9): 1055-1059. doi:10.1038/ejen.2014.126

29. Lopez PE, Evans M, King BR, Jones TW, Bell K, McElduff P, et al.: A randomized comparison of three prandial insulin dosing algorithms for children and adolescents with Type 1 diabetes. Diabet Med 2018; 35: 1440-1447. doi:10.1111/dme. 13703

30. Danne T, Phillip M, Buckingham BA, Jarosz-Chobot P, Saboo B, Urakami T, et al.: ISPAD Clinical Practice Consensus Guidelines 2018: Insulin treatment in children and adolescents with diabetes. Pediatric Diabetes 2018; 19(Suppl. 27): 115-135. doi:10.1111/pedi.12718

31. Pankowska E, Ładyżynski P, Foltynski P, Mazurczak K: A randomized controlled study of an insulin dosing application that uses recognition and meal bolus estimations. J Diabetes Sci Technol 2017; 11(1): 43-49. doi:10.1177/1932296816683409

Közlésre érkezett: 2019. április 29.

Közlésre elfogadva: 2019. május 16.

\section{A levelezésért felelös szerző címe:}

\section{Dr. H. Nagy Katalin}

Békés Megyei Központi Kórház, Pándy Kálmán

Tagkórház, Gyermekosztály

5700 Gyula, Semmelweis út 1.

E-mail: hajdukati.gyk@gmail.com 